\title{
Legal Certainty on Children Custody as Divorce Victims
}

\author{
Mutmainah $^{1}$, Azis Budianto ${ }^{2}$ \\ \{muthmainnahmursalinsamad72@gmail.com ${ }^{1}$, azis_budianto@borobudur.ac.id $\left.{ }^{2}\right\}$ \\ Universitas Borobudur, Jakarta, Indonesia ${ }^{1,2}$
}

\begin{abstract}
This paper presents a civil law perspective related to legal certainty for child custody as divorce victims. Through normative juridical research methods and literature studies, it is found that a child has the right to decide to be cared for by one of his parents. According to Article 41 of Law Number 1 of 1974 concerning Marriage, a divorced husband and wife are still obliged to maintain and educate children according to their needs. As long as the child is under 12 years old, the mother has the right to custody of her child, even though she is the party filing the divorce suit. The child's father is also required to provide care for the child until the child is married or is an adult.
\end{abstract}

Keywords: Children; Custody; Divorce; Civil Law

\section{Introduction}

As per Article 1 of Law Number 1 of 1974 concerning Marriage (then, at that point, alluded to as the Marriage Law), it states "Marriage is an internal and external connection between a man and a lady as a couple to shape a timeless (family) and glad dependent on God Almighty."[1] The purpose of marriage itself is broadly stated by God to get peace of life, to keep one's honor out of sight, and to have children. Besides from a religious perspective, marriage also aims to expand and strengthen family relationships, as well as to build a better future for individuals, families, and society.[2] However, a reality experienced by human beings in marriage is the emergence of disputes, injuries, and lack of trust between husband and wife that sometimes lead to household shocks.

The issue of divorce was also a much-discussed issue before the Marriage Act. In reality, in society, a marriage ends in a divorce, and there are times when the divorce occurs because of the arbitrary actions of the men.[3] The husband and wife's divorce results in three things, firstly, the marital bond is broken. Secondly, the marital property includes joint ownership must be divided. And thirdly, the care of the child must be left to one of the fathers or mothers.

Divorce can be said to be a catastrophe, but if it occurs then, the catastrophe needs to be endeavor so it wouldn't cause another severe disaster. Divorce is only allowed to use in an emergency, causing enormous harm. Therefore, divorce is the emergency door of marriage for mutual safety. A heavy burden will occur on couples, especially children after divorce, whereas generally, children have the same rights as when their parents were not divorced, including: 
a. Love, even though parents are divorced.

b. The child must continue to receive love, and the child has the right to determine whom he will live with.

c. Education.

d. Health attention

e. Decent place to stay.

The four basic elements above must be met by parents towards their children if they take the consequences for divorce. But we can't deny it either, if at the time the parents' divorce, then one of the parties cannot fulfill the child's rights so that his/her rights are neglected. These rights are protected in the 1945 Constitution of the 4th Amendment as a constitutional basis which has explicitly regulated the importance of protecting human rights, counting the freedoms of ladies and youngsters, as expressed in Article 28 B section (2), which expresses "Each kid has the option to endurance, development and advancement and the right to assurance from viciousness and segregation (Constitution of the Republic of Indonesia Year 1945: Th). Law of the Republic of Indonesia No. 23 of 2002 concerning Child Protection, Article 1 section 12 which expresses: "Youngsters' privileges are essential for basic liberties that should be ensured, secured, and satisfied by guardians, families, networks, government and the state" and furthermore in the Convention on the Rights of the Child which has additionally been sanctioned by our country. [4]

The issue of child custody is often a debate between husband and wife when they want to divorce. Therefore there must be a solution so as not to harm the parents and the child. Child custody is a right for children who are still small because they need supervision, care, implementation of their affairs, and parents who educate them. This paper presents a civil law perspective related to legal certainty for child custody as divorce victims.

\section{Research Method}

The type of this research is lawful exploration. Lawful exploration (legitimate examination) is to track down the reality of cognizance,[5] that are there any lawful guidelines as per lawful standards and are there standards as orders or denials observing legitimate standards, and regardless of whether an individual's activities are under lawful standards (not just keeping the guideline of law) or lawful standards? The exploration strategy utilized is standardizing juridical, utilizing writing considers as a tool in collecting data. The collected data was then analyzed using descriptive analysis to present the information comprehensively.[6]

\section{Discussion}

According to Article 26 of the Civil Code concerning Marriage, it is expressed that marriage was a lawful connection between a man and a person for quite a while.[7] The law views marriage only on a civil relationship, which means that a valid marriage is only a marriage that meets the requirements set out in the Civil Code. Article 199 of the Civil Code states that the dissolution of a marriage is divided into 4 (four) types, namely:

a. The death of one of the parties.

b. The absence of husband and wife for 10 (ten) years and followed by a new marriage 
c. The existence of a judge's decision Divorce Divorce is the abolition of marriage by a judge's decision,

d. The demands of one of the parties to the marriage.

In case there is a separation, there is no commitment to live respectively once more. The Law Number 1 of 1974 concerning Marriage this matter isn't managed, yet we can see its arrangements in Government Regulation Number 9 of 1974 that is the carrying out guideline of Law Number 1 of 1974, specifically Article 24 section (1) expresses that: When a separation claim is in progress, in line with the offended party or the respondent dependent on the thought of the potential risks, the court might permit the couple not to reside in another house to forestall the danger that would emerge assuming the husband and spouse live in one home once more.

With respect to legitimate results of separating a marriage because of separation for a couple, it isn't controlled exhaustively. There is just one article that controls it, to be specific Article 41 Letter C of Law Number 1 of 1974, that peruses "The court might oblige the ex to give everyday costs as well as decide a commitment for his ex."[8] Determining something this obligation must be based on law. Having children in a marriage is something every couple dreams about. For them, children are an extraordinary gift from God that they must be cared for and treated as well as possible. Problems will arise when the marriage that has been established breaks up for various reasons which are finally justified by the court by reading out the divorce decision. At the time of the breakup of a marriage due to the divorce of husband and wife, children will inevitably become victims.

Juridically, the situation of a kid in a marriage is controlled in Article 42 of Law Number 1 of 1974 on Marriage that contains a conclusive arrangement that a real youngster is a kid brought into the world in, or because of a legitimate marriage. Then, at that point, as per the constraint arrangements in Article 43 passage (1) of Law Number 1 of 1974 on Marriage, a youngster conceived illegitimately has just a common relationship with his mom and his mom's family. It implies that Law No. 1 of 1974 on Marriage Article 45 section (1) and passage (2) contains an arrangement that the two guardians should keep up with and teach their youngsters well. The commitment is legitimate until the youngster weds or can remain on their own, which commitment proceeds regardless of whether the marriage between the two guardians is broken.

As per Article 229 of the Civil Code, the court decides the gatekeeper of the minor. In the event that the party alloted as gatekeeper can't pay for the support and schooling of the youngster, then, at that point, as indicated by article 230 of the Civil Code, the appointed authority can decide the measure of cash that should be paid by the other party to fund minors. As indicated by the Marriage Law Number 1 of 1974 article 41, among others: Both mother and father are obliged to keep up with and teach their youngsters, exclusively dependent on the kid's advantages, in case there is a debate in regards to the control of the kids, the court gives a choice. [8]

In the Child Protection Law No. 23 of 2002, Article 14 expressed that each youngster has the option to be really focused on by his folks except if there are legitimate reasons as well as lawful standards demonstrating that the partition is to the greatest advantage of the kid and is a last thought.[9] Parents (father or mother) have equal and equal rights as parents to care for, maintain and care for and protect children's rights. Most importantly, the ability of parents to nurture and care for children.[10]

The arrangements of Article 28 B (2) of the 1945 Constitution, underlined that each kid has the privilege to endure, develop and create and is qualified for assurance from brutality and separation to acquire insurance from savagery, abuse, and segregation, [11] so that parents 
have a crucial role in the child's growth period, in addition to providing a decent life as well as giving love to their children.

The legal rules regulated in this Marriage Law are filtered which ones can be made into living law and must be applied. In claiming the living cost for children, it is usually the mother who will act to file a claim against the father (ex-husband) if her ex-husband does not fulfill his obligations in providing a living for the children under his care. The demands made by the mother (ex-wife) are not only regarding the fulfillment of the child's living and education costs but also the issue of child care. Those things are done by the District Court in several decisions concerning the issue of child care. Then after a divorce and it is decided that the child is with his mother, his ex-husband will be given the obligation to provide a living and the cost of education and maintenance of the child.

In many cases, the District Court resolving cases of child care and child maintenance responsibilities tends to delegate the responsibility for child care to the biological mother, and the father is burdened with the responsibility to meet all costs of child care and education so that the child can stand alone. In child protection after divorce, it is not only limited to fulfilling the provisions of the law. As long as divorced parents consciously and in good faith are willing to carry out their obligations following existing stipulations, the problems caused by divorce, especially child problems, will be minimized.

Not always custody of children always falls to the mother, the father also has the same rights. However, in general, court decisions and considerations prioritize the mother as the holder of child custody provided that the mother must meet several conditions, that the basis for the decision is the interests and benefits of the child, both for the physical, spiritual, intellectual, and religious growth of the child. The implementation of child care after the divorce is not only a formality but also to educate children to aim his or her growth both physically and psychologically.

If the mother who has been given the right to care for the child turns out to have neglected her obligations, the punishment for her is to revoke the child's right to care for the child or the right of guardianship through a request from the party who objected to the mother's action to the District Court. Following the meaning and formulation of the Act, that to determine the right of guardianship, the right to care for the child that must be considered is in the legal interest of the child. Nevertheless, if found that the father to have neglected his obligations of the custody of the child that was delegated to him, the custody of his child will be revoked. So, the judge must pay attention if the child is cared for by his mother or father to have a better social life and welfare guarantee. The foremost thing is the ability of parents to nurture and care for their children.

Thus, who will later hold custody of the child, either the mother or the father, the priority is to support the positive growth of the child. However, even though child custody can only be with one parent, after the divorce, both parents are still obliged to maintain and take care of their children until they are adults even though they do not live in the same house.

\section{Conclusion}

Marriage Law Number 1 of 1974 article 41 (a) that guardians are obliged to really focus on and teach their kids exclusively to serve the youngster, KHI article 98 (1) that as far as possible for kids who can remain solitary or as grown-ups is 21 years, as long as the kid the individual isn't genuinely or intellectually handicapped or has not hitched. Not always custody of the child falls to the mother, yet the father also has the same rights over the child. In giving 
a decision on child custody that fell to the father, the judge is following the Marriage Law Number 1 of 1974 article 49 (1) that parents can be revoked of their power over a child for a specific time at the request of the other parent with a court decision if he neglects his obligations towards his child and if he behaves badly. Therefore, if the father is considered more worthy to care for and educate his child adequately, the judge has the authority to give his decision.

\section{References}

[1] Undang-Undang Republik Indonesia Nomor 1 Tahun 1974 Tentang Perkawinan dan Kompilasi Hukum Islam [Law of the Republic of Indonesia Number 1 of 1974 concerning Marriage and the Compilation of Islamic Law], 5th Edition. Bandung: Citra Umbara, 2010.

[2] A. Sosroatmodjo and A. W. Aulawi, Hukum Perkawinan di Indonesia [Marriage Law in Indonesia]. Jakarta: Bulan Bintang, 1978.

[3] M. Ashsubli, "Undang-Undang Perkawinan Dalam Pluralitas Hukum Agama (Judicial Review Pasal Perkawinan Beda Agama)," J. CITA Huk., vol. 3, no. 2, pp. 289-302, Jan. 2016, doi: 10.15408/jch.v2i2.2319.

[4] D. David and Z. Fakrulloh, "Analysis of the Traditional Marriage of the Dayak Kadorih Tribe in the Perspective of Law Number 1 of 1974 Concerning Marriage," 2021, doi: 10.4108/eai.6-3-2021.2306410.

[5] P. M. Marzuki, Penelitian Hukum (Edisi Revisi). Jakarta: Prenada Media Group, 2014.

[6] J. Ibrahim, "Teori dan Metode Penelitian Hukum Normatif [Normative Legal Research Theories and Methods]," Bayu Media, Malang, 2006.

[7] H. Hadikusuma, Hukum Perkawinan Indonesia [Marriage Law in Indonesia]. Bandung: Mandar Maju, 1990.

[8] W. Darmabrata, Tinjauan Undang-Undang No. 1 Tahun 1974 Tentang Perkawinan Beserta Undang-Undang dan Peraturan Pelaksanaannya. Jakarta: Gitama Jaya, 2003.

[9] "Law of the Republic of Indonesia Number 23 of 2002 concerning Child Protection."

[10] R. Saraswati, Hukum Perlindungan Anak Di Indonesia [Child Protection Law in Indonesia]. Bandung: PT. Citra Aditya Bakti, 2009.

[11] A. Kamil and Fauzan, Hukum, Perlindungan dan Pengangkatan Anak di Indonesia [Law, Protection and Adoption of Children in Indonesia]. Jakarta: Raja Gravindo Persada, 2008. 